人工知能の知

一機械学習手法を用いた脳内情報解読と脳機能解明に向けた取り組み一

小林 一郎

お茶の水女子大学基幹研究院自然科学系

\title{
Intelligence of Artificial Intelligence: A Study on Brain Decoding using Machine Learning and the Analysis of Brain Functions
}

\author{
Ichiro Kobayashi, Ph.D.
}

Advanced Sciences, Graduate School of Humanities and Sciences, Ochanomizu University

In this paper, we propose a brain decoding method for the generation of natural language descriptions based on human brain activity by a deep learning model.

In addition, to elucidate brain functions, we focused on predictive coding, which is hypothesized to be one of the functions of the cerebral cortex. We investigated the agreement between the predictions of deep learning model and the actual brain activity data to test the predictive coding hypothesis. Furthermore, we propose a method for generating images from human brain activity data by using the same validation model.

(Received November 9, 2020; accepted December 7, 2020)

Key words: brain decoding, deep learning, fMRI

Jpn J Neurosurg（Tokyo）30: 120-127, 2021

\section{はじめに}

近年，脳神経科学において，人間の脳内で処理される 意味情報表現を定量的に分析する研究が盛んになってい る。中でも，ヒト大脳皮質における階層情報表現と深層 学習の階層情報表現に相同性があることが Yamins ら ${ }^{9)}$ に よって示されたこと，また，人工知能技術の 1 つである 深層学習の勃興などにより, 深層学習モデルを作業モデ ルとして, 脳内での情報処理機構を解明する研究が盛ん になっている。これらの背景を受けて, 本研究では, 国 立研究開発法人情報通信研究機構脳情報通信融合研究セ ンター西本グループとの共同研究で行った，機械学習手 法を用いた脳内情報解読および脳内機能解明に向けた 2
つの取り組みについて紹介する.

\section{人エニューラルネットワークの発展}

昨今の人工知能ブームの火付け役になったのが深層学 習といわ机る，深層学習とは，それまでの人工ニューラ ルネットワーク（artificial neural networks：ANN）におけ る信号伝達の層をさらに増やすことによってモデルを複 雑にしたモデルである。ここで，人工ニューラルネット ワークとは, 1943 年に神経生理学者・外科医であった McCulloch と論理学・数学者であったPittsによって提案 されたニューロンにおける信号伝達モデルを基礎にし， それを複数のニューロンをつなぐネットワークとして表

連絡先：小林一郎， $\bar{\top} 112-8610$ 文京区大塚 2-1-1 理学部 3 号棟 503 室お茶の水女子大学基幹研究院自然科学系

Address reprint requests to: Ichiro Kobayashi, Advance Sciences, Graduate School of Humanities and Sciences, Ochanomizu University Room 503, Science Bld. 3, 2-1-1 Otsuka, Bunkyo-ku, Tokyo 112-8610, Japan 


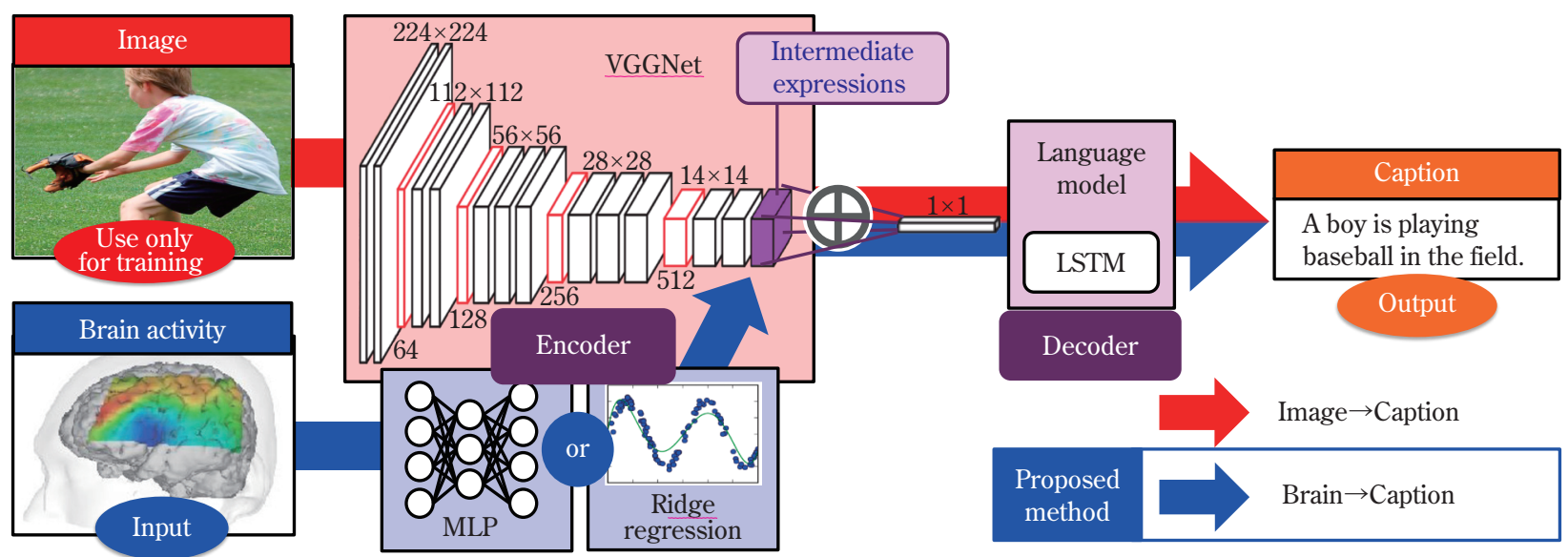

Fig. 1 Overview of our proposed method

Natural language descriptions based on visual stimuli are generated using a caption generation system.

現し，入力情報に対して適切な出力情報が得られるよう にネットワーク自体をモデルとして学習可能にする人工 知能技術の 1 つである。代表的なネットワークの構造と して，入力から出力までの方向が 1 方向であり，複数の ニューロンが 1つの層としてまとめられ，多層にわたる 形をとるものが採用される。

深層学習とは，この層の構造がたかだか 3 層くらいま でしかなかった，それまでのANNの構造に対して，層 をさらに増やす技術が開発されたことにより，より複雑 な入出力関係を表現することが可能となった ANNを 使った機械学習手法のことを指す。深層学習による ANN のモデルは，2012 年に開催された IMAGENET Large Scale Visual Recognition Challenge 2012 (ILSVRC2012) と いう画像認識コンペティションにおいて，それまでの精 度を大幅に超える高い精度で優勝し，その技術が広く知 られるようになった。深層学習は，画像識別や音声認識 などのそ机までの手法の精度を上回り，さまざまな識別 問題に適用されるようになった。一方で，深層学習では 入出力の関係を表現するモデルを構築する際に, 大量の 入出力ペアのデータが ANN モデルの挙動を決定するパ ラメータを学習するために必要となるという課題も存在 する.

\section{脳内情報解読}

\section{一画像刺激脳活動データからの文生成一}

人に画像を見せた際の脳内の活動状態を，核磁気共鳴 装置（fMRI）を用いて観測し，その観測データから脳内 の状態を表現する文を, 深層学習を用いて生成する手法
を提案した。一般に，深層学習を使って fMRIによる脳 活動デー夕から文を生成するモデルを構築するには, 大 量の脳活動デー夕と文のペアデータが必要とされるが, それらを収集することはコストが大きい。また，個々人 の脳の形状には個人差がある。これらのことは, ANNの モデルを学習するための入出力デー夕を大量に用意する ことを困難にさせ，さらに，収集した複数被験者のデー 夕は，モデルの学習において異なる入出力データとして 扱われるため, 安定したモデルを構築するために必要な デー夕数を増やすことを困難にさせている，そのため， 本研究では, 脳活動デー夕とは関係なく, 大量の画像と それを説明する文のペアデータを用いて，画像に映る事 象を文で説明する深層学習モデルを事前に構築し，その モデルを援用することで少量の脳活動デー夕からその脳 活動の状態を説明する文を生成する手法を開発した。

\section{1 脳活動の状態を説明する文生成手法}

本研究において, 与えられた画像がもつ特徵を多次元 の成分をもつべクトルの值（このことを「画像特徴」量 という）として抽出する深層学習モデル VGGNet ${ }^{6}$ を用 いて, 取り出された画像特徵量を, fMRI で観測された画 像刺激の脳活動デー夕から推定し, 推定された画像特徴 量から文章を生成する手法を提案する。これにより, 脳 活動デー夕から画像特徴量を推定する部分のモデルを構 築することで，脳活動データから文を直接生成すること を可能にする．Fig. 1 に手法の全体像を示す.

本提案モデルの主部分である, 画像からその内容を反 映した文を生成するモデルとして, 深層学習モデルの代 表的なモデルである画像キャプション生成モデル8) 
Table 1 Natural language descriptions generated by four models based on visual stimuli

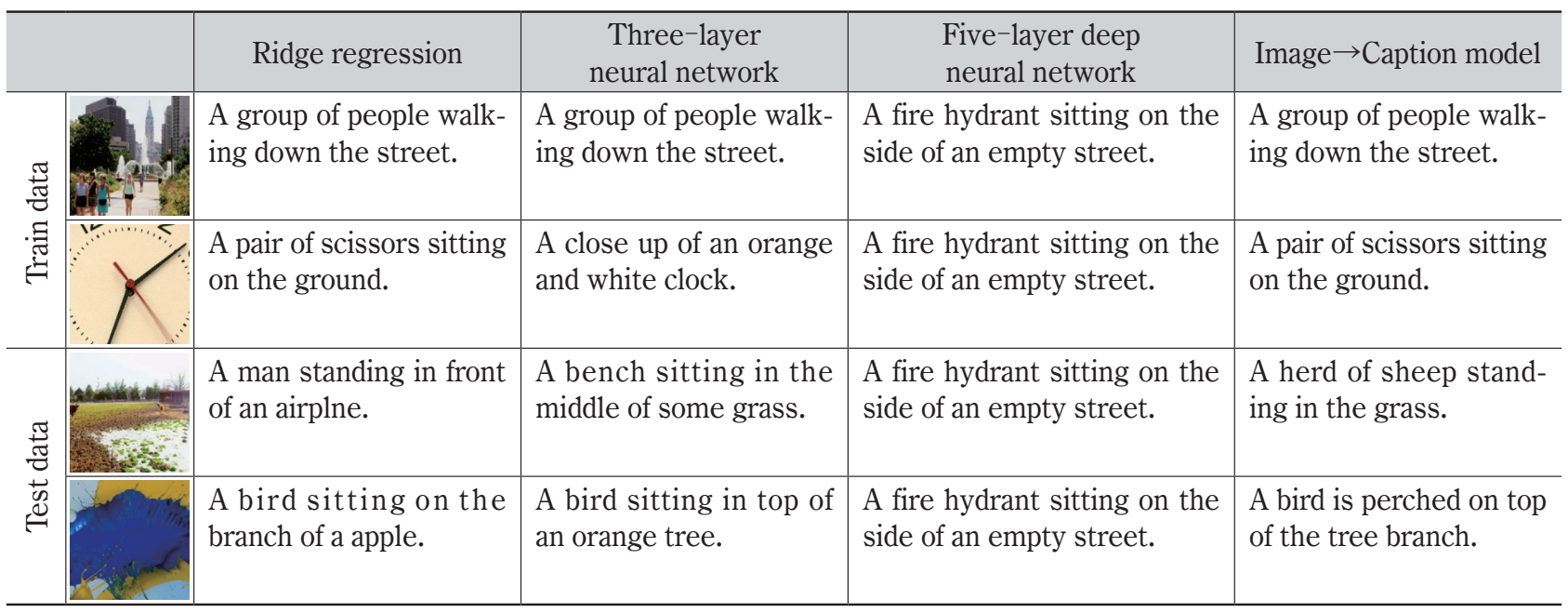

いる，画像キャプション生成モデルは，画像からその特 徵量を畳み込みニューラルネットワーク（CNN）によっ て抽出し，その抽出された画像特徵量が再帰型ニューラ ルネットワーク（recurrent neural networks：RNN）への 入力情報となり，RNNによって生成された文が出力され る. RNN とは, 逐次的に入力される情報に対応して出力 を行うANNのモデルのことを指し，単語の系列で表現 される文や音声，時系列のセンサー情報などを扱うこと ができるANNである.

提案手法では，VGGNet を用いて画像から抽出した画 像特徴量に対して, 同じ画像を被験者に見せた際の脳活 動デー夕から推定を行う。この際，脳活動デー夕から視 覚刺激として与えられた画像の特徴量を推定するモデル として, Ridge 回帰，3層の ANN と 5 層の深層ニューラ ルネットワーク (deep neural networks: DNN) の3つを 用いて実験を行った。ここで, Ridge 回帰とは, 入出力 の関係を捉える回帰モデルを作る手法の 1 つであり，モ デルを入力に対する出力の誤差を小さくする多項式関数 として近似表現する際に関数の係数が大きくならない制 約が付されたものである. 回帰モデルを構築する際に頻 繁に利用される。

\section{2 実験}

脳活動と画像特徵量の対応関係を学習するためのデー タセットとして，動画像を 1 名の被験者に見せたときの 血中酸素濃度依存性信号（BOLD 信号）を fMRI を用い て記録した脳活動デー夕および fMRI のデータ収集と同 期して動画像から切り出した静止画を使用する. fMRI による立体撮像 $96 \times 96 \times 72$ ボクセルのうち, 皮質に相 当する約 65,000 次元分のデー夕列を入力とし，そのとき
見ている画像から VGGNetにより抽出された 4,096 次元 の画像特徵量との対応を捉えたモデルを上述した 3 種類 の回帰モデルにより構築する.モデル構築のための学習 用デー夕数は 4,500（9,000 秒分のデータ: 2 秒ごとに 1 デー夕取得) である.

\section{3 実験結果と考察}

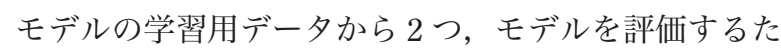
めのデー夕から 2 つを選んだ合計 4 つの脳活動デー夕に 対して生成した文章およびそのときの画像，また，比較 のため画像キャプション生成モデルによる生成文章を

Table 1 に示す.

Table 2 から脳活動データのみを入力として, 人が解釈 可能な画像内容を表現する文章が生成されていることが 確認できる。 また, 本実験で使用したデータセットには, 正解文となる脳活動デー夕から生成した文章は存在しな いため, 画像キャプション生成モデルにより評価デー夕 刺激画像 300 サンプルから文章を生成し，そのうち適切 であると人手で判断された 60 サンプルを正解デー夕と して用いた. Ridge 回䚻, 3 層 ANN を用いたモデルにつ いては，学習用デー夕に対しての脳活動データからの生 成文章と画像からの生成文章が一致していることから, 構築するモデルが過度にデー夕に一致してしまう過学習 と呼ばれる現象は起こしているものの, モデルの構築手 法自体には問題がないことが確認できる。しかし，5層 DNNではどのような入力に対してもまったく同じ文章 が生成され，評価デー夕に対しては Ridge 回帰や 3 層 ANN でも脳活動から生成した文章と画像から生成した 文章の一致度は低くなった。このことは，モデルに含ま れる学習すべきパラメー夕数に比べて, 学習用デー夕数 
Table 2 Natural language descriptions generated based on the response of highly-correlated brain regions to visual stimuli

\begin{tabular}{|l|l|l|l|l|l|l}
\hline & $\begin{array}{c}\text { 3,538 voxels } \\
(\text { c.c. }>0.2)\end{array}$ & $\begin{array}{c}\text { 5,961 voxels } \\
(\text { c.c. }>0.15)\end{array}$ & $\begin{array}{c}\text { 9,923 voxels } \\
(\text { c.c. }>0.1)\end{array}$ & $\begin{array}{c}\text { 21,437 voxels } \\
(\text { c.c. }>0.05)\end{array}$ & $\begin{array}{l}\text { 65,665 voxels } \\
(\text { all cortex })\end{array}$ & $\begin{array}{l}89,206 \text { voxels } \\
(+ \text { subcortex })\end{array}$ \\
\hline $\begin{array}{l}\text { A young man is } \\
\text { doing tricks on } \\
\text { his skateboard. }\end{array}$ & $\begin{array}{l}\text { A man is playing } \\
\text { tennis on the } \\
\text { court. }\end{array}$ & $\begin{array}{l}\text { A young man is } \\
\text { playing tennis on } \\
\text { the court. }\end{array}$ & $\begin{array}{l}\text { A man is playing } \\
\text { tennis on the } \\
\text { court. }\end{array}$ & $\begin{array}{l}\text { A man is playing } \\
\text { tennis on the } \\
\text { court with his } \\
\text { racket. }\end{array}$ & $\begin{array}{l}\text { A man is playing } \\
\text { tennis on the } \\
\text { court with his } \\
\text { racket. }\end{array}$ \\
\hline $\begin{array}{l}\text { A man sitting on } \\
\text { the ground with } \\
\text { an umbrella. }\end{array}$ & $\begin{array}{l}\text { A polar bear is } \\
\text { standing in the } \\
\text { water. }\end{array}$ & $\begin{array}{l}\text { A dog laying on } \\
\text { the ground next } \\
\text { to an orange } \\
\text { frisbee. }\end{array}$ & $\begin{array}{l}\text { A dog laying on } \\
\text { the ground next } \\
\text { to an orange } \\
\text { frisbee. }\end{array}$ & $\begin{array}{l}\text { A black and } \\
\text { white dog laying } \\
\text { on the ground. }\end{array}$ & $\begin{array}{l}\text { A dog is sitting } \\
\text { on the floor in } \\
\text { front of an open } \\
\text { door. }\end{array}$ \\
\hline
\end{tabular}

(4,500サンプル)が少ないことが主な原因と考えられる.

また，fMRIによって取得した皮質全体の脳活動を捉 えたデー夕は約 65,000 次元と高次元であるため, モデル のパラメータの学習に困難が生じた。このことを考慮し て, Nishida $ら^{3)}$ の研究において画像特徵量から脳活動 データへの回帰の推定值において，相関性が高かったボ クセルに限定した脳活動データを用いてモデルを構築し

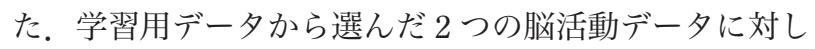
て，このモデルを用いて文章を生成した結果を Table 2 に示す。

Table 2 より, 高次元のデー夕を用いて構築したモデル のほうが画像の内容をより適切に記述する文章が生成さ れていることがわかる. また, 約 65,000 次元の皮質全体 を用いたモデルが最もよく学習されたと考えられる。一 方，高い推定精度を観測したボクセルを選別することに より作られた低次元のデー夕を用いて学習したモデルか らは，画像の内容にそぐわない文章の生成が見受けられ た．脳活動データの次元を減らすことで, モデルの学習 は易化したにもかかわらず生成される文章の質が落ちて いることから，画像刺激に反応しにくい脳領域にも文章 を表現するために必要な情報が含まれていることが推察

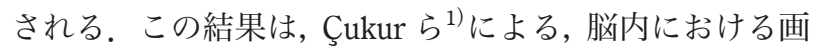
像刺激の処理が特定の部位によるものではなく，広い範 囲にわたって行われているという主張を支持している.

\section{4 まとめ一提案する脳内情報解読手法の限界と 展望一}

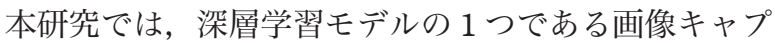
ション生成モデルを援用し, 画像刺激として得られた脳 活動デー夕からその内容を文章として出力する手法を提 案した。この手法の精度を向上させより頑健なものにす るためには, 大量の脳活動データが必要となり, この点 が提案手法のボトルネックとなっている。一方で，入力
データとして, 脳の特定の部位における情報を用いて, その結果を出力させることが可能であることから, 将来 的には, 脳内にどの部分が文章を生成するための意味表 象を操作するのに機能しているかなど，fMRIにより観 測したデータから脳の機能をシミュレーションすること などが期待できると考える。

\section{深層学習モデルを用いた予測符号化の検証}

脳神経科学分野では，大脳皮質において予測符号化 (predictive coding) と呼ばれる知覚の予測機能が働いて いるとの仮説が存在する ${ }^{4)}$. 予測符号化は，ヒトが知覚 した情景の次の状態を予測し，予測の状態と実際に観測 された状態との差分を処理することにより，吅長性を低 減した効率的な情報処理を実現しているとされている. 大脳皮質においては，高次領域・低次領域間に双方向の 接続が存在し，高次領域で生成された予測が低次領域へ と伝播，予測と観測の差分が低次領域から高次領域へと フィードバックされることにより予測モデルが更新され るという一連の処理が行われ, 精度の高い予測を行うこ とが可能になるとされている。この情報伝達機構を模倣 し, さまざまな計算機モデルが構築されている(2)7).

その代表的なものの 1 つである PredNet ${ }^{2}$ は, 深層学習 の枠組みで構築された予測符号化のモデルであり，入力 として現時刻までの動画像を与えられた下で将来の画像 フレームを予測・生成するタスクを行う過程で汎用性の 高い特徴を学習するモデルとして提案されている.

PredNetでは画像の特徵を掴むのに適したCNN，およ び時系列デー夕を扱うのに適した RNNの1種である長・ 短期記憶 (long short-time memory：LSTM）とCNN を結 合し時空間に対して広がりをもつデー夕を扱えるように したモデルである convolutional LSTM ${ }^{5}$ を用いて動画像 の特徵を捉え, 予測画像の生成を行っている. PredNet 


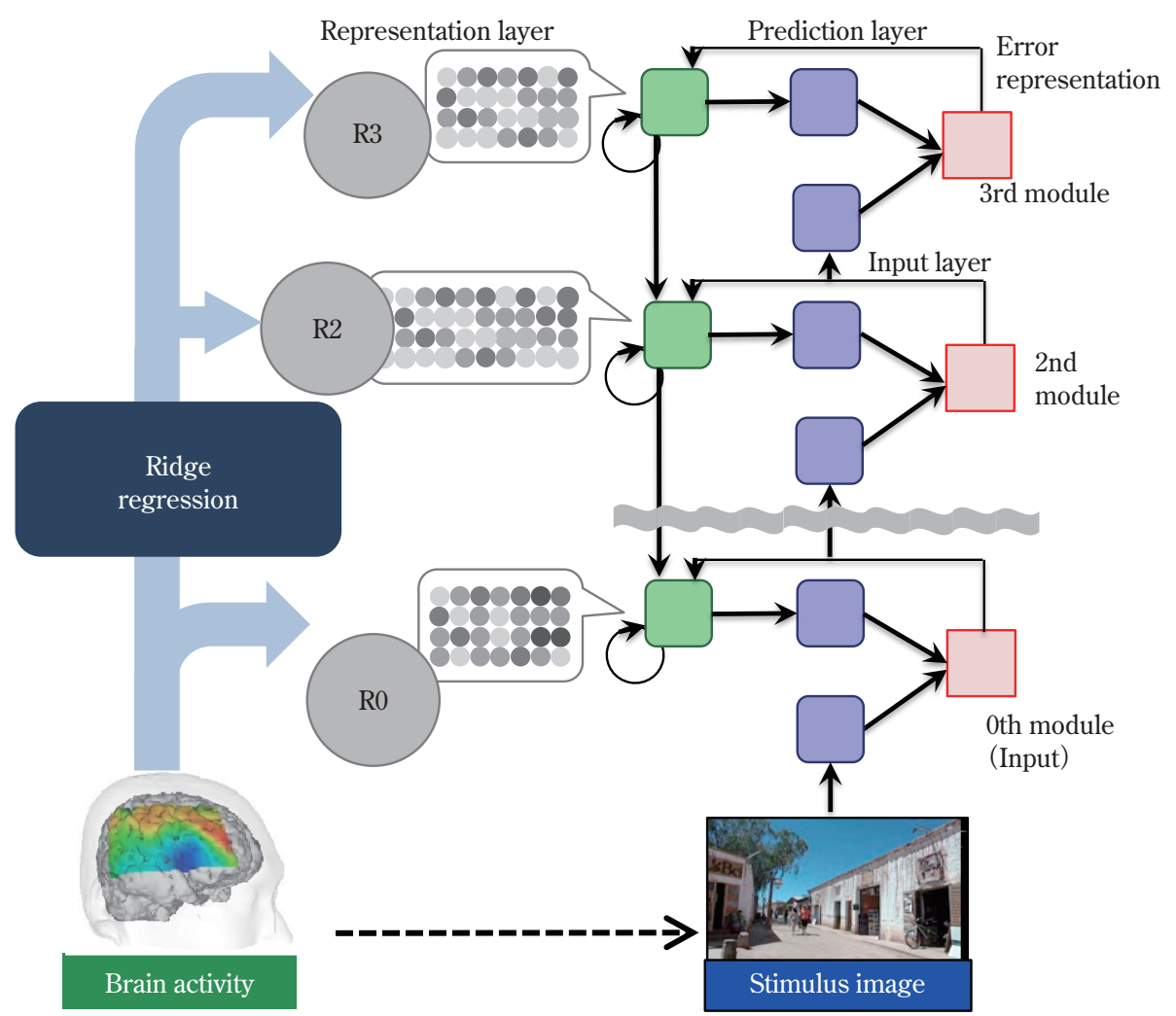

Fig. 2 Overview of PredNet predictions and their relationship with brain activity in the experiment

Table 3 Correlation between the actual representations and the representations derived from brain activities

\begin{tabular}{|c|c|c|c|c|c|c|c|c|c|c|c|c|}
\hline \multirow{2}{*}{$\begin{array}{c}\text { Representa- } \\
\text { tions }\end{array}$} & \multicolumn{12}{|c|}{ Correlation coefficient } \\
\hline & 0.5 & 1.0 & 5.0 & 10.0 & 100.0 & $1 \mathrm{~K}$ & $10 \mathrm{~K}$ & $25 \mathrm{~K}$ & $50 \mathrm{~K}$ & $100 \mathrm{~K}$ & $1 \mathrm{M}$ & $10 \mathrm{M}$ \\
\hline R0 & 0.2490 & 0.2491 & 0.2495 & 0.2499 & 0.2570 & 0.2868 & 0.3125 & 0.3174 & 0.3152 & 0.3055 & 0.2384 & 0.1652 \\
\hline $\mathrm{R} 2$ & 0.06695 & - & - & - & - & - & - & 0.1448 & 0.1562 & 0.1662 & 0.1804 & 0.1671 \\
\hline R3 & 0.06984 & 0.06986 & 0.06998 & 0.07013 & 0.07253 & 0.08299 & 0.09355 & 0.09867 & 0.1022 & 0.1040 & 0.09288 & 0.07160 \\
\hline
\end{tabular}

では，予測した状態と観測した状態の差分を踏まえて， 次の状態を予測するという情報の処理がなされており， 予測符号化として仮説されているものと同じ処理を表現 している.

\section{PredNet を用いた脳内での予測符号化の検証}

学習されたPredNetに対して, 脳活動測定時に被験者 に提示された刺激動画像を入力として与え，その際の representation モジュールにおける特徵表現と脳活動と の対応関係を Ridge 回帰を用いて学習する。対応関係の 学習後, 脳活動からモデル内部の特徵表現の推定を行 い，推定された特徴表現と PredNetに刺激動画像を適用 して得られた特徵表現との相関係数を算出する.
PredNetの一部および脳活動との対応関係を Fig. 2 に 示す.

PredNet 内部の特徵表現と脳活動デー夕の対応関係の 学習に際して, 特徵表現は脳活動測定時の刺激動画像を 静止画像として切り出し PredNetに入力した際に, PredNet を構成する 4 層（最下層から順に R0， R1， R2， R3 と各層を呼ぶ）で観測された特徵量を用いた。脳活動 デー夕は動画像視聴時の被験者の血中酸素濃度に依存す る信号（BOLD 信号）を, fMRIを用いて取得した皮質に 相当する約 65,000 次元の脳活動デー夕を使用した. 各層 の特徴量と脳活動データのペアを, 学習データ 4,497 対, 評価デー夕 300 対として学習を行った。ここで学習デー 夕とは，モデルのパラメー夕を決める際に使用される入 

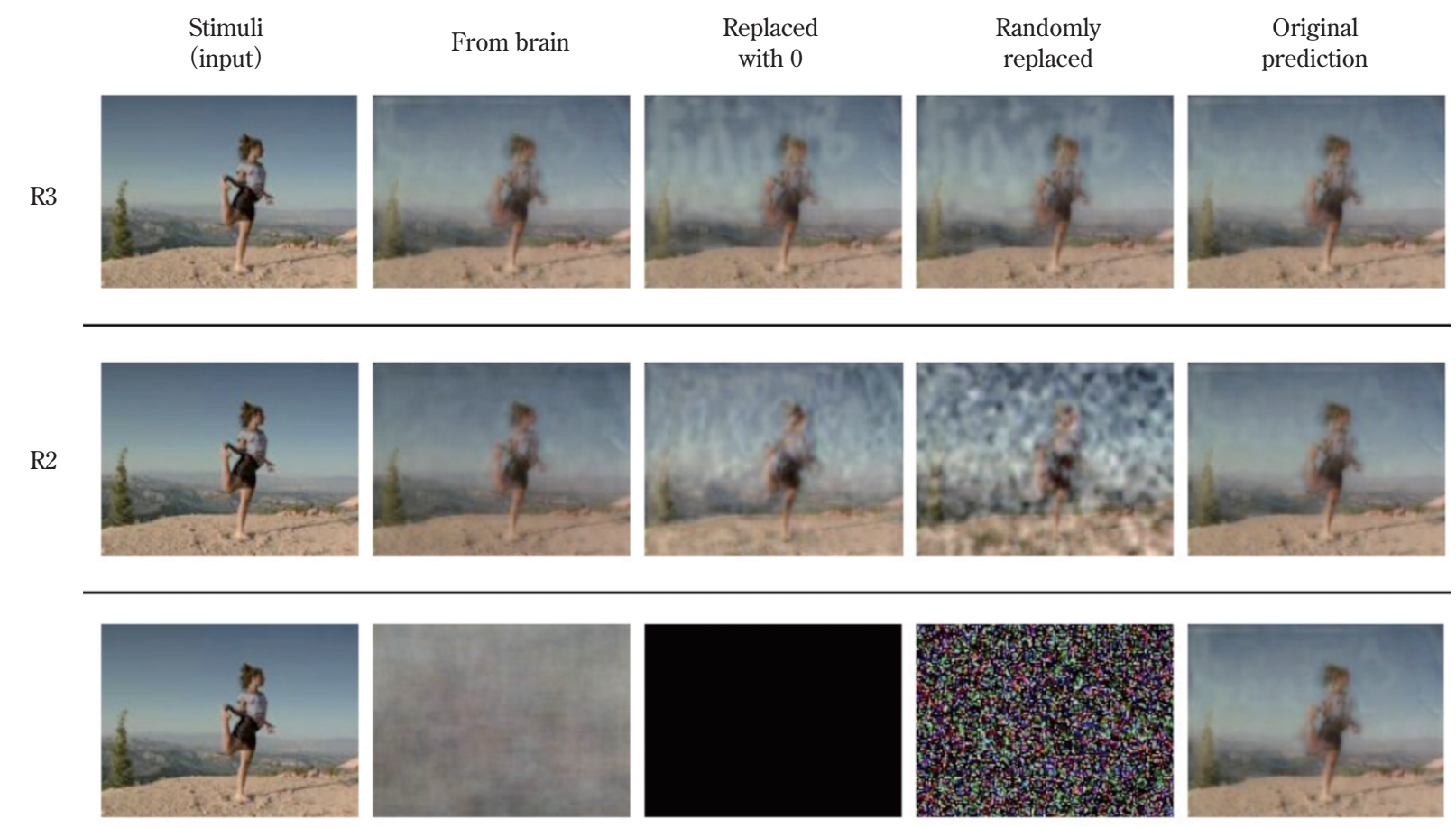

R0
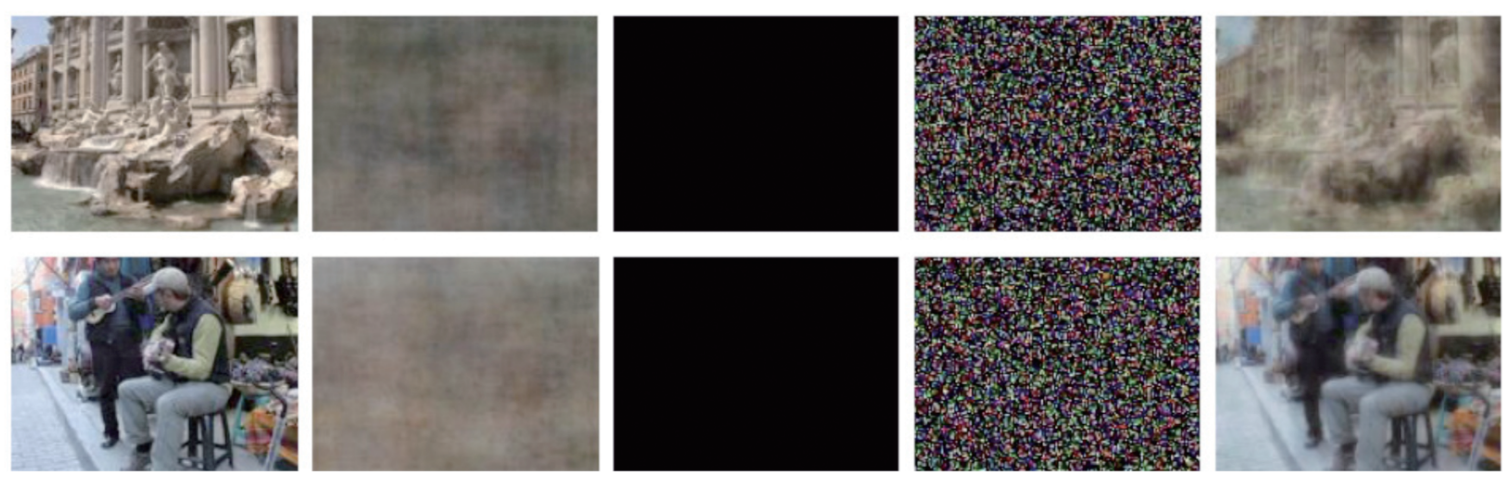

Fig. 3 Examples of images generated from various representations

出力のペアデータのことを指す。機械学習では学習に よって構築するモデルは，モデル構築に使用されていな い入力に対しても正しい結果を出力できる汎化性能が重 要視される。 そのため, 構築したモデルが信頼できる結 果を出力できているかを, 検証するためのデータとして 評価デー夕を用いる。これらのデー夕を使用し, Ridge 回帰学習時のモデルパラメータを獲得する際の調整係数 となる正則化項の重みパラメー夕を変更しつつ学習した。

Ridge 回帰を用いて推定した R0，R2，R3 でのそれぞ れの特徵量と刺激画像から得られた R0, R2, R3 でのそ れぞれの特徵量の相関係数を Table 3 に示す. 第 1 層 (R1) は, その状態が 230,400 次元と非常に高次元で表現され ていたため, 今回, Ridge 回帰によるモデル構築は行わ なかった。

Ridge 回帰を用いて推定された特徵表現と刺激画像入
力下の特徵表現の相関係数は, 最下層（R0）において正 則化項の重みパラメータ $\lambda=2.5 \times 10^{4}$ のきに 0.317 程 度となり, これはノイズの多い脳活動を扱う脳神経科学 分野においては，相関を認めるに值するとの知見があ る。一方, 第 2 層（R2）および第 3 層（R3）では有意と 取れる相関性は認められない結果となった。

\section{2 脳活動データを用いた画像生成}

学習した Ridge 回帰を用いて評価用の脳活動データか ら推定した特徵量から得た PredNet の出力值を元に画像 生成を行った。また, 検証のため, 各特徵表現を 0 およ び $[-1.0 \sim 1.0]$ のランダムな值で置換した場合の画像生 成も行った。生成画像の例を Fig. 3 に示す.

左から順に該当時刻の入力画像, Ridge 回帰を用いた 脳活動からの推定値，0，[-1.0～1.0］のランダムな值で 


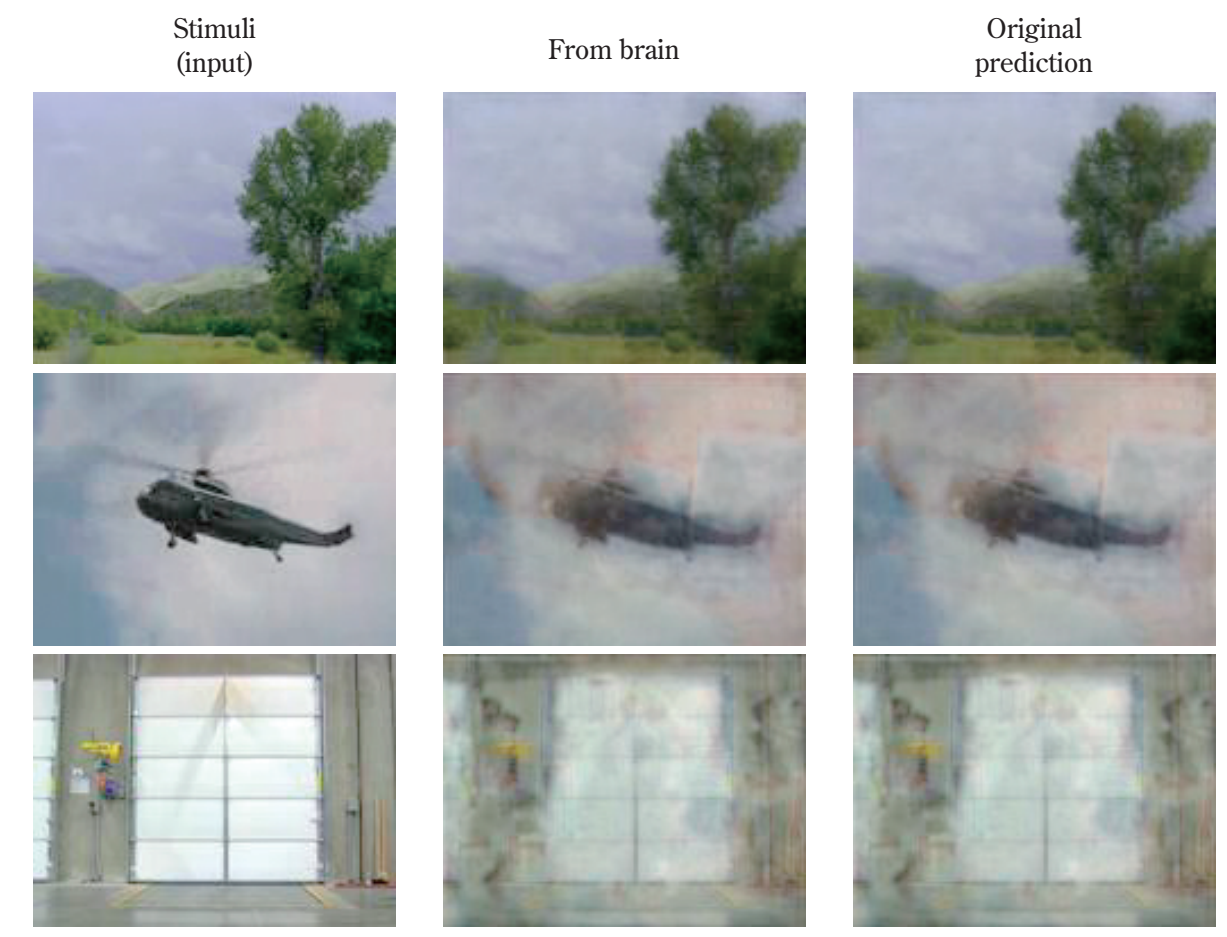

Fig. 4 Examples of images generated based on brain activity training data Left: Stimulus (input) image at the time step.

Middle: Images generated based on representations derived from brain activity training data for ridge regressions.

Right: Original predicted images generated by PredNet.

置換した生成画像, 正解值からの生成画像となっている.

R3 に関しては，0 およびランダムな值で置換した場合 は，ほぼ同様の画像が生成されていることが見て取れ， 異なる入力を与えた場合においても大きな相違をもたら さないことから, PredNet 内部において第 3 層は十分に 機能していないのではないかと推測される。一方で, Ridge回帰を用いて脳活動から推定した值でR3を置換し た場合には，0およびランダムと比較して正解值からの 生成画像に近い画像を生成できている。しかし, 総じて, R3 は值を置き換えても生成画像に大きな影響を及ぼす ことはない。つまり, PredNet内部においてはR3からの 情報は画像生成へ大きく寄与しないと考えられる。 R2 に関しては, 推定值で置換した場合, 0 およびランダム な值で置換した場合と比較して, 正解值から生成した画 像に近い画像を生成できていることがわかる，R0では エラーシグナルからの補正を直接受け取らないため, 脳 活動からの推定值のみに依存して画像生成を行ってお り, 生成画像は視認性の低いものとなった。これは, 対 応関係を高精度のモデルとして学習できなかったことが 原因の 1 つであると推測される。

また, 同じモデルに対して, 学習用の脳活動デー夕か ら推定した特徵表現で PredNet 内部の representation モ
ジュールの出力值を置換したうえでの画像生成を行った 際の結果を Fig. 4 に示す.

Fig. 4 から学習に用いたデー夕からはPredNetによる 生成画像とほぼ同じものを生成できていることがわか る.このことから大量のデー夕を用いてモデルを学習す ることができれば，評価デー夕を使ってもこのような画 像生成が可能になることが期待できる.

\section{3 まとめ一提案する予測符号化手法の限界と展 望一}

本研究では，大脳皮質における予測符号化を模倣した 深層予測モデルである PredNet と脳活動の相関を定量的 に評価する試みとして, PredNetを構築し，その特徵表 現と脳活動との相関関係を考察した。また脳活動から各 特徴表現を推定し, PredNetに入力して画像生成を行い, PredNet 内部の各層の予測画像生成における貢献の度合 いを検証した。画像生成の精度を向上させるためには, 前章で紹介した脳内情報解読手法と同じく, 大量の学習 データが必要となる点がボトルネックとなる. また, 提 案手法を用いて画像刺激の処理に貢献する脳の特定部位 を発見するなどの検証が行えると期待できる. 


\section{全体まとめ}

本研究では, 画像刺激の脳活動データから文章を生成 する脳内情報解読手法および予測符号化の計算モデルの 1つであるPredNetを対象にして，その内部状態と脳活 動データとの相関性を検証し, 有意な関係を確認した。 また, 脳活動データから画像生成を試みた。これらの研 究を通じて, 人工知能の 1 つの手法である深層学習を用 いることによって, 脳内の各部が担うさまざまな情報処 理を解明する可能性について紹介した。

謝辞 本研究は, 科学研究費補助金 $16 \mathrm{H} 01540$ および 17H01797 の支援を受けたものである。ここに謝意を表す.

\section{COI}

著者は, 自己申告による COI 報告書を日本脳神経外科コン グレス事務局に提出しています。本論文に関して開示すべき COI はありません.

\section{文 献}

1) Çukur T, Nishimoto S, Huth AG, Gallant JL: Attention during natural vision warps semantic representation across the human brain. Nat Neurosci 16: 763-770, 2013.
2) Lotter W, Kreiman G, Cox D: Deep Predictive Coding Networks for Video Pre diction and Unsupervised Learning. ICLR 2017, 2016. https://arxiv.org/abs/1605.08104 (accessed: March 1, 2017)

3) Nishida S, Huth AG, Gallant JL, Nishimoto S: Word statistics in large-scale texts explain the human cortical semantic representation of objects, actions, and impressions. The 45th Annual Meeting of the Society for Neuroscience, 333.13. Chicago, USA. 2015.

4) Rao RP, Ballard DH: Predictive coding in the visual cortex: a functional interpretation of some extra-classical receptive-field effects. Nat Neurosci 2: 79-87, 1999.

5) Shi X, Chen Z, Wang H, Yeung D, Wong W, Woo W: Convolutional LSTM Network: A Machine Learning Approach for Precipitation Nowcasting. Neural Information Processing Systems (NIPS) 2015. pp.802-810, 2015.

6) Simonyan K, Zisserman A: Very Deep Convolutional Networks for Large-Scale Image Recognition. ICLR 2015.

7) van den Oord A, Li Y, Vinyals O: Representation Learning with Contrastive Predictive Coding. 2019, https://arxiv. org/abs/1807.03748 (accessed Janurary 22, 2019)

8) Vinyals O, Toshev A, Bengio S, Erhan D: Show and Tell : A Neural Image Caption Generator. 2015 IEEE Conference on Computer Vision and Pattern Recognition (CVPR). pp.31563164, 2015

9) Yamins DL, Hong H, Cadieu CF, Solomon EA, Seibert D, DiCarlo JJ: Performance-optimized hierarchical models predict neural responses in higher visual cortex. Proc Natl Acad Sci U S A 111 : 8619-8624, 2014.

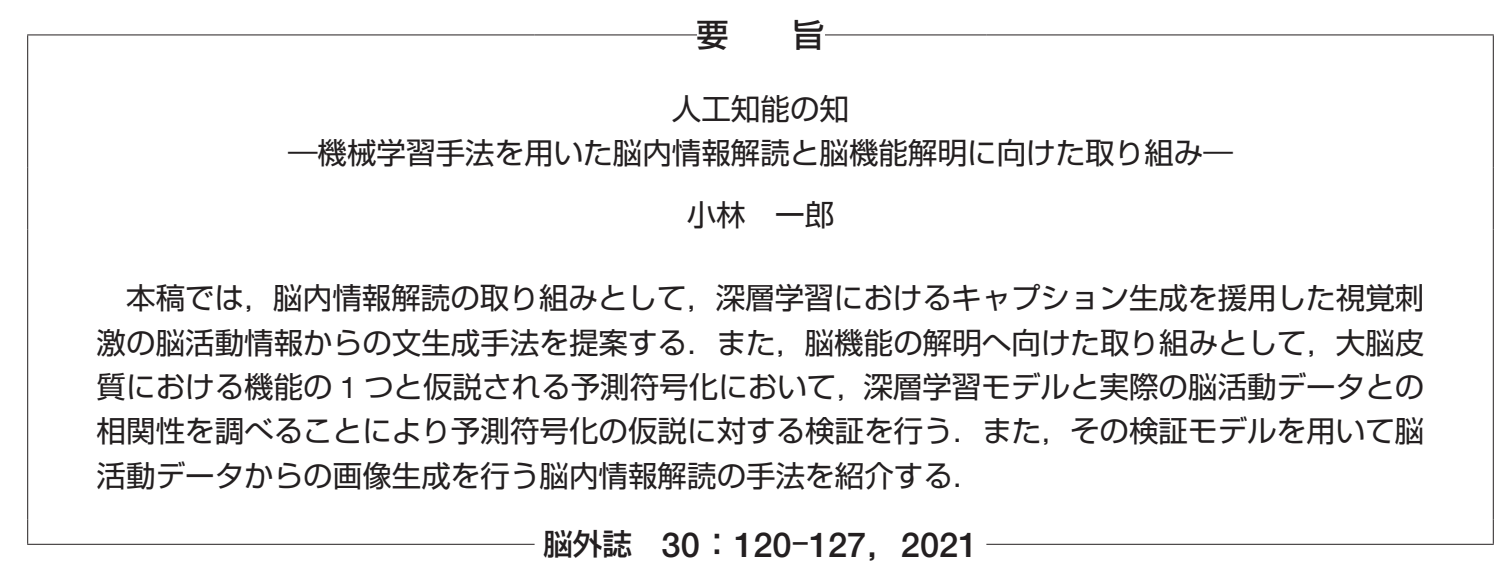

